\title{
Exogenous silicon application contributes to wear resistance in Kentucky bluegrass by improving anatomical structure and cell wall components
}

\author{
Jinbo $\mathrm{Li}^{1}$, Shigang $\mathrm{Li}^{2}$, Lixin $\mathrm{Xu}^{1}$, Xuehua Puyang ${ }^{2}$, Yangfan Zheng ${ }^{1}$, Guilong Song ${ }^{1}$ and $\mathrm{Yi} \mathrm{Xu}^{3}$ \\ ${ }^{1}$ Turfgrass Research Institute, Beijing Forestry University, Beijing, China \\ ${ }^{2}$ Shenzhen Tech and Ecology \& Environment Co. Ltd., Shenzhen, China \\ ${ }^{3}$ Department of Plant Biology, Rutgers University, New Brunswick, USA
}

\begin{abstract}
Summary
Wear stress is unavoidable for sports turf and lawn, which could crush the leaves, stems and affect root growth negatively by soil compaction. Silicon (Si) fertilizer can strengthen the cell wall, which could be beneficial to the enhancement of turfgrass wear tolerance. The objective of this study was to identify the effect of $S i$ application $\left(0,25,50,100 \mathrm{~g} \mathrm{~m}^{-2}\right)$ on wear resistance of Kentucky bluegrass. The application of $100 \mathrm{~g} \mathrm{~m}^{-2} \mathrm{Si}$ on Kentucky bluegrass could lead to silicon deposition in leaf, thickened stratum corneum, and increased the sclerenchyma number and coverage. The content of cellulose and acid detergent lignin (ADL) increased significantly under $50 \mathrm{~g} \mathrm{~m}^{-2}$ and $100 \mathrm{~g} \mathrm{~m}^{-2}$ applications. After wear treatment, the significant improvements for turf quality were found under $50 \mathrm{~g} \mathrm{~m}^{-2}$ and $100 \mathrm{~g} \mathrm{~m}^{-2}$, compared to no silicon control. The content of $\mathrm{H}_{2} \mathrm{O}_{2}$ reached a peak at $2 \mathrm{~h}$ of wear treatment and enzyme activity of SOD, POD and CAT also increased at first and then dropped under wear treatment. Moreover, high concentration of silicon fertilizer can reduce the electronic leakage (EL) and malondialdehyde (MDA) content. The turf quality was much better in density and color under $50 \mathrm{~g} \mathrm{~m}^{-2}$ and $100 \mathrm{~g} \mathrm{~m}^{-2}$ applications. The result showed that a high concentration of silicon fertilizer can protect the membrane system and decrease membrane lipid peroxidation via reinforcing the anatomical structure and increasing the cell wall components.
\end{abstract}

Keywords

turfgrass, silicon, antioxidants, chlorophyll, enzyme activity, wear resistance

\section{Abbreviations}

ADL: acid detergent lignin; MDA: malondialdehyde; EL: electronic leakage; Si: silicon; ROS: reactive oxygen species; SOD: superoxide dismutase; CAT: catalase; POD: guaiacol peroxidase; APX: ascorbate peroxidase; $\mathrm{H}_{2} \mathrm{O}_{2}$ : hydrogen peroxide; BSI: biogenic silicon; TCA: trichloroacetic acid; KI: potassium iodide; EDTA: ethylenediaminetetraacetic acid; PMSF: phenylmethylsulfonyl; PVP: polyvinylpyrrolidone; DTT: dithiothreitol.

\section{Introduction}

Silicon ( $\mathrm{Si}$ ) is the second most abundant element in the soil following oxygen (Ma, 2005). Although silicon is not con-

\section{Significance of this study}

What is already known on this subject?

- Silicon application on turfgrass has been shown to improve plant wear tolerance.

What are the new findings?

- Silicon application improved wear tolerance of Kentucky bluegrass by strengthening cell wall structure, lignin content, and antioxidant activities.

What is the expected impact on horticulture?

- Our results indicated that silicon is a beneficial element in turfgrass improvement of wear tolerance. In addition, it also aids understanding the mechanisms of silicon-mediated wear tolerance in Kentucky bluegrass.

sidered as an essential element for plants, it is a crucial element for many terrestrial plant species, especially for grasses (Schoelynck and Struyf, 2016). It has been proved that Si has the capacity to modify plant physiological processes in a way that provides benefits to growth, development and/or stress responses, which constitutes a distinct category of biostimulants (Valente et al., 2004; Ma and Yamaji, 2006). Beneficial effects associated with Si application have also been reported for many dicotyledons, especially when the plants are exposed to abiotic or biotic stress (Ma, 2004; Chen et al., 2011; Kim et al., 2014). Silicon is probably the only element which is able to enhance the resistance to multiple stresses (Ma, 2004). Si has been found to serve as essential constituent of plants, as well as fertilizers. Its accumulation in plants is beneficial for maintaining sustainable production (Guntzer et al., 2012). One typical example is rice, which accumulates Si up to $10 \%$ on a dry weight basis in the shoot. High accumulation of $\mathrm{Si}$ in rice has been demonstrated to be necessary for healthy growth and high and stable production (Ma, 2004). Beneficial effects of Si are usually obvious in crops which actively accumulate $\mathrm{Si}$ in their shoots. This is because most of the beneficial effects of Si are expressed through Si deposited on the leaves and stems. Si is deposited as a $2.5 /$ z-thick layer in the space immediately beneath the thin cuticle layer, forming a cuticle-Si double layer in the leaf blade of rice (Yoshida et al., 1962). Si is reported to have the potential to alleviate heavy metal stress by reducing lipid peroxidation and increasing heavy metals binding to the cell wall. Moreover, it is an alternative to the extensive use of phytosanitary 
and fertilizers to mitigate soil nutrient depletion (Zhang et al., 2015; Guntzer et al., 2012). Silicon fertilization by natural silicates has the potential to mitigate environmental stresses and soil nutrient depletion and as a consequence is an alternative to the extensive use of phytosanitary and NPK fertilizers for maintaining sustainable agriculture (Guntzer et al., 2012). However, the most important benefit of Si application is to increase grass wear tolerance.

Turfgrass wear resistance has often been correlated with several biological and physiological parameters such as total cell wall (Shearman and Beard, 1975), modified acid detergent fiber (Canaway, 1981), sucrose phosphate synthase and sucrose synthase activity, stem and leaf moisture (Trenholm et al., 2000), leaf flexibility (Sun and Liddle, 1993), evapotranspiration rate, leaf chlorophyll concentration, membrane permeability, leaf peroxidase activity, spectral reflectance, tissue potassium (Shearman and Beard, 1973; Carroll and Petrovic, 1991) and silica concentration (Trenholm et al., 2001; Lulli et al., 2011). Several reports of anatomical changes in plant cell wall imposed by Si deposition have correlated some beneficial effects with Si (Ma, 2004). Studies also have hinted to a functional role of biogenic $\mathrm{Si}$ (BSi), an amorphous hydrated matrix of $\mathrm{Si}$, in aquatic vegetation as a strength component (Schoelynck et al., 2010, 2016). The Si deposition on cell walls on the epidermal surfaces of leaves, stems, and hulls provides mechanical strength and rigidity to plant tissues (Isa et al., 2010). Moreover, Si application could modify cell wall architecture and compounds, by forming a double-layer structure in cell wall, increasing the thickness of the stem wall and diameter of vascular cell (Kido et al., 2015), and improving the lignin structure by lignification (Zhang et al., 2013). Si content in aquatic vegetation also shows intriguing relations with other strength components such as cellulose and lignin (Schoelynck and Struyf, 2016). Extensive research on epidermal cells have shown that in Si-fertilized plants, plant defenses were stimulated through the production of phenolic compounds, callose, or methylaconitate (phytoalexin) (Bélanger et al., 2003; Ghanmi et al., 2004; Rémus-Borel et al., 2005, 2009). Here, it is more probably a mechanical factor that plays a role as leaves containing Si are more difficult to graze (Guntzer et al., 2012). It is feasible to apply external Si to plant, in order to strengthen its cellular rigidity, and therefore improve its mechanical resistance. Wear causes a direct injury to plant tissues by pressure, scuffing, abrasion, and tearing (Beard, 2005; Bonos et al., 2001). Turf cover, visual quality, and shoot density have been commonly used to evaluate wear tolerance (Canaway, 1981; Shearman and Beard, 1975). Membrane permeability is closely associated with cell membrane composition and physiological status (Mansour, 2012). Increased electronic leakage (EL) may be partially the result of cell membrane damage by reactive oxygen species (ROS), especially under the heavy traffic stress. More traffic stress tolerance in Japanese zoysiagrass was associated with more peroxidase activity, less EL, and higher shoot density (Han et al., 2008). The clear beneficial effects of Si deposition in cell wall is considered to be closely related to the wear resistance of plant (Trenholm et al., 2000; Brosnan et al., 2005). In fact, wear could result in unavoidable injury for leaf and shoot of turfgrass (Shearman and Beard, 1975), which is directly affected by the structure of cell wall. Furthermore, it could also be affected by the content of cell wall components. There was significant correlation between cell wall components (cellulose, hemicellulose and lignin) and the wear resistance (Shearman and Beard, 1975; Brosnan et al., 2005). Previous work has suggested that foliar Si levels and the abrasiveness of grass leaves were well correlated, since more than $70 \%$ of the variation in abrasiveness across 18 different grass species could be explained by Si content (Massey et al., 2007). However, Si levels and abrasion are not always closely linked. It seems that the size, shape and density of phytoliths and $\mathrm{Si}$ rich spines will influence the abrasiveness of the leaf surface. It is possible that differential $\mathrm{Si}$ depositions in different grass species at their leaf surfaces could be vital for their various leaf abrasiveness levels (Hartley et al., 2015).

Therefore, the purpose of this study was to investigate the possible effects of silicon fertilizer on the anatomical structure and cell wall components for Kentucky bluegrass, and what important role they did play in improving turf quality and physiological metabolism related with wear resistance.

\section{Materials and methods}

\section{Plant material and growth conditions}

Kentucky bluegrass (Poa pratensis L.) cv. Nuglade were planted in plastic pots ( $30 \mathrm{~cm}$ in diameter, $25 \mathrm{~cm}$ in height) filled with a mixture of peat and fine sand ( $\mathrm{v}: \mathrm{v}=1: 1.5)$ at $18 \mathrm{~g}$ pure live seed (PLS) $\mathrm{m}^{-2}$. They were grown in a greenhouse with a temperature regime of $28 \pm 1^{\circ} \mathrm{C} / 18 \pm 1^{\circ} \mathrm{C}$ (day/night), $70 \%-80 \%$ relative humidity, and average $14 \mathrm{~h}$ photoperiod at $400 \mu \mathrm{mol} \mathrm{m}^{-2} \mathrm{~s}^{-1}$ at Beijing Forestry University. The plants were trimmed once every week, and irrigated every $3 \mathrm{~d}$. The plants were also fertilized once with turf fertilizer (19-7-14) at $10 \mathrm{~g} \mathrm{~m}^{-2}$.

\section{Silicon fertilizer and wear treatments}

The granulated silicon fertilizer (Meicun Mutual Biotechniques, Guangdong, China), containing 10\% (w/w) $\mathrm{SiO}_{2}$ with pH 5-6, was applied two months after seeding, with concentrations of $0,25,50$, and $100 \mathrm{~g} \mathrm{SiO}_{2} \mathrm{~m}^{-2}$. In details, different amounts (0/7.065/14.13/28.26 g) of fertilizer was first dissolved in $500 \mathrm{~mL}$ distilled water, and poured into pots, respectively. Each silicon fertilizer treatment had six replicates (three for control and three for wear treatment). Wear treatment was conducted two months after silicon fertilizer application. Thick rubber flaps were put into woven bags (bottom area $35 \times 30 \mathrm{~cm}$, with $15 \mathrm{~kg}$ weight on top of it), then the bags were pulled back and forth 30 times on turf as wear treatment for one time. (Wang et al., 2002). The plant leaf damage was visually assessed to keep uniform leaf break, curling, and wilting among all pots. The experimentation was arranged in a randomized block design, in which the plant pots were randomly placed in the greenhouse, and shuffled every week to minimize the confounding factors within the greenhouse.

\section{Leaf anatomical structure}

Anatomical structure was observed on $45 \mathrm{~d}$ after silicon fertilizer application using 5 plants randomly sampled from each pot and 3 mature leaves from the middle part were taken on each plant. Leaves were cut into $10-\mu \mathrm{m}$ thickness in conventional paraffin method. Leaf sections were stained by safranin-fast green and anatomical structure were observed under LEICA DP70 microscope (LEICA Company, Germany).

\section{Cell wall components analysis}

Cellulose and acid detergent lignin were measured at 15 , 30 and $45 \mathrm{~d}$ after silicon fertilizer application, using Fanz Detergent Fiber methods (Geng et al., 1994). 


\section{Measurement of hydrogen peroxide content $\left(\mathrm{H}_{2} \mathbf{O}_{2}\right)$}

The content of $\mathrm{H}_{2} \mathrm{O}_{2}$ was measured at $0,0.5,1,2,4$ and $8 \mathrm{~h}$ after wear treatment. Approximately $0.1 \mathrm{~g}$ fresh shoot were ground in liquid $\mathrm{N}_{2}$, using mortar and pestle. After that, $2 \mathrm{~mL}$ of $0.1 \%(\mathrm{w} / \mathrm{v})$ TCA was added to the ground powder. The homogenate was then transferred to $2 \mathrm{~mL}$ microcentrifuge tube. The mixture was centrifuged at $15,000 \mathrm{~g}$ at $4^{\circ} \mathrm{C}$ for $20 \mathrm{~min}$, and $1 \mathrm{~mL}$ supernatant was collected. $1 \mathrm{~mL}$ of $10 \mathrm{mM}$ potassium phosphate buffer $(\mathrm{pH} 7.0)$ and $2 \mathrm{~mL}$ of $1 \mathrm{M} \mathrm{KI}$ were added to the supernatant. Hydrogen peroxide $\left(\mathrm{H}_{2} \mathrm{O}_{2}\right)$ concentration was estimated based on the absorbance of the supernatant at $390 \mathrm{~nm}$. Pure water was used instead of KI for blank measurement. The calculated standard curve was $y=0.0012 x-0.0138\left(R^{2}=0.9976\right)$, while $x$ was hydrogen peroxide concentration in $\mu \mathrm{mol} \mathrm{g}^{-1}$, and y was A390 (Velikova et al., 2000).

\section{Measurement of antioxidant enzyme activity}

The activity of antioxidant enzyme was measured at 0,5 , 10 and $15 \mathrm{~d}$ after wear treatment. Approximately $0.15 \mathrm{~g}$ fresh leaf were ground in liquid $\mathrm{N}_{2}$, using mortar and pestle. After that, $2 \mathrm{~mL}$ of $50 \mathrm{mM}$ potassium phosphate buffer ( $\mathrm{pH} 7.8$ ) containing $1 \mathrm{mM}$ ethylenediaminetetraacetic acid (EDTA), $1 \mathrm{mM}$ phenylmethylsulfonyl (PMSF), 1\% ( $\mathrm{w} / \mathrm{v}$ ) polyvinylpyrrolidone (PVP), and $1 \mathrm{mM}$ dithiothreitol (DTT) was added to the ground powder. The homogenate was then transferred to $2 \mathrm{~mL} \mathrm{mi-}$ crocentrifuge tube. The mixture was centrifuged at $15,000 \mathrm{~g}$ at $4^{\circ} \mathrm{C}$ for $20 \mathrm{~min}$, and supernatant was collected for assay of enzyme activity (Zhang and Kirkham, 1996). The SOD activity was measured according to the method of Giannopolitis and Ries (1977) and the activity of CAT and POD was estimated by the method of Zhang and Kirkham (1996) by following changes in absorbance at $240,470 \mathrm{~nm}$, respectively.

\section{Measurement of electrolyte leakage (EL)}

Shoot samples $(0.2 \mathrm{~g})$ were sampled at $2 \mathrm{~h}$ after wear treatment on $0 \mathrm{~d}$, and then every $5 \mathrm{~d}$ after wear treatment. The leaf EL was measured according to Blum and Ebercon (1981) with minor modifications. Leaf samples were thoroughly washed with distilled water and kept in closed vials with $10 \mathrm{~mL}$ of deionized water. Each leaf sample $(0.1 \mathrm{~g})$ was cut into $1 \mathrm{~cm}$ pieces, immersed in $20 \mathrm{~mL}$ distilled water, and agitated for $24 \mathrm{~h}$ under room temperature. The initial EL was measured as $\mathrm{EL}_{1}$. The leaf sample was then boiled for $30 \mathrm{~min}$, cooled down to room temperature, and measured for final EL $\left(\mathrm{EL}_{2}\right)$. Distilled water was used as control $\left(\mathrm{EL}_{0}\right)$. The leaf EL was calculated as $\left(\mathrm{EL}_{1}-\mathrm{EL}_{0}\right) /\left(\mathrm{EL}_{2}-\mathrm{EL}_{0}\right) \times 100 \%$.

\section{Measurement of malondialdehyde (MDA) content}

Malondialdehyde is the final product of lipid peroxidation in plant tissues and was quantified according to the procedure described by Zhang and Kirkham (1996) with slight modifications. The MDA content was measured for $0.1 \mathrm{~g}$ fresh leaf sample and then ground to powder in liquid nitrogen. The leaf powder was then homogenized in $1.5 \mathrm{~mL}$ of $5 \%$ $(\mathrm{w} / \mathrm{v})$ trichloroacetic acid (TCA) solution. The homogenate was centrifuged at $10,000 \mathrm{~g}$ for $20 \mathrm{~min}$, and $0.5 \mathrm{~mL}$ of supernatant was added to $1 \mathrm{~mL} 20 \%(\mathrm{w} / \mathrm{v})$ TCA containing $0.5 \%$ $(\mathrm{w} / \mathrm{v})$ thiobarbituric acid. The mixture was incubated at $95^{\circ} \mathrm{C}$ for $30 \mathrm{~min}$, quickly cooled on ice, and then centrifuged at $10,000 \mathrm{~g}$ at $4^{\circ} \mathrm{C}$ for $10 \mathrm{~min}$. The absorbance of supernatant was measured at 532 and $600 \mathrm{~nm}$ using a spectrophotometer. The concentration of MDA was calculated using the formula: MDA (nmol g-1 FW) $=\left[(\text { A532-A600) } / 155]^{*} 1000 *\right.$ dilution factor (Heath and Packer, 1968).

\section{Turf quality evaluation}

The turf quality was evaluated according to the National Turfgrass Evaluation Program (NTEP) after $15 \mathrm{~d}$ of wear treatment, including density, texture, color and uniformity. A visual rating with 1 to 9 scale is used with 1 equaling no density and 9 equaling maximum density for density evaluation. A visual rating of texture is based on a 1 to 9 rating scale with 1 equaling coarse and 9 equaling fine. A visual rating with 1 to 9 scale is used for color evaluation, with 1 being straw brown and 9 being dark green. A visual rating with 1 to 9 scale is used for uniformity, with 1 being more than $50 \%$ of bare land, wilted grass in the area, and 9 being well uniformed, evenly green. The final score is calculated as the average of the above four scores. All the index testings were repeated 4 times.

\section{Statistical analysis}

The data were analyzed by analysis of variance (ANOVA), and difference (LSD) test was employed to determine differences among the treatments at $\mathrm{P}=0.05$ level.

\section{Results}

\section{Changes of leaf anatomical structure after silicon fertilizers application}

Thickened corneum of leaf was stained red as shown in Figure 1. Under $100 \mathrm{~g} \mathrm{~m}^{-2}$ silicon fertilizer, thickened corneum almost covered all of the leaf lower epidermal cells. Under the control treatment, only a few epidermal cells were
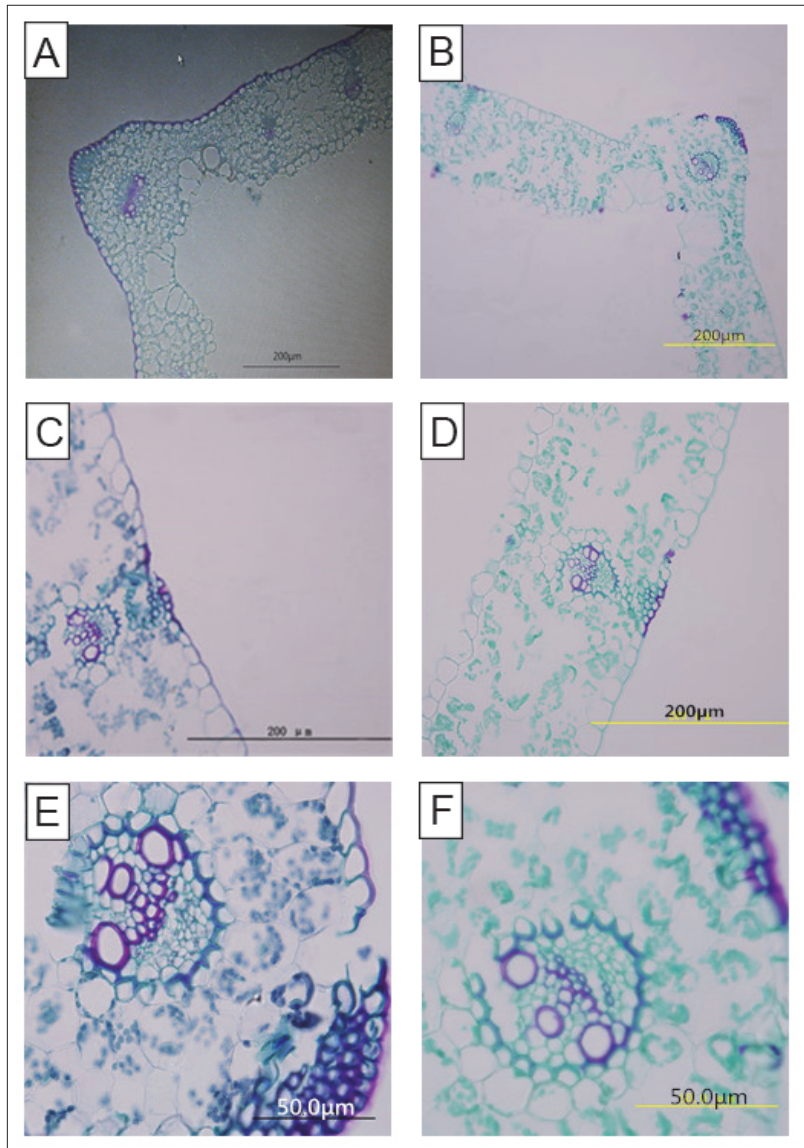

FiguRE 1. Anatomical structures of leaves under silicon fertilizers and control. A, C, E for leaves under $100 \mathrm{~g} \mathrm{~m}^{-2}$ silicon fertilizer, B, D, F for leaves of control. A/B: Leaf corneum; C/D: Leaf vascular bundle; E/F: Leaf sclerenchyma. 
stained red (Figure 1B). The degree of corneum coverage and thickness was obviously larger than the non-silicon control, as is shown in Figures $1 \mathrm{~A}$ and $1 \mathrm{~B}$.

Under $100 \mathrm{~g} \mathrm{~m}^{-2}$ silicon treatment, leaf sclerenchyma was stained deeply compared to the control, indicating that there were more sclerenchyma in the leaf with $100 \mathrm{~g} \mathrm{~m}^{-2}$ silicon treatment (Figure 1E). However, there is no difference between the higher silicon treatment and control in the quality of vascular bundle.

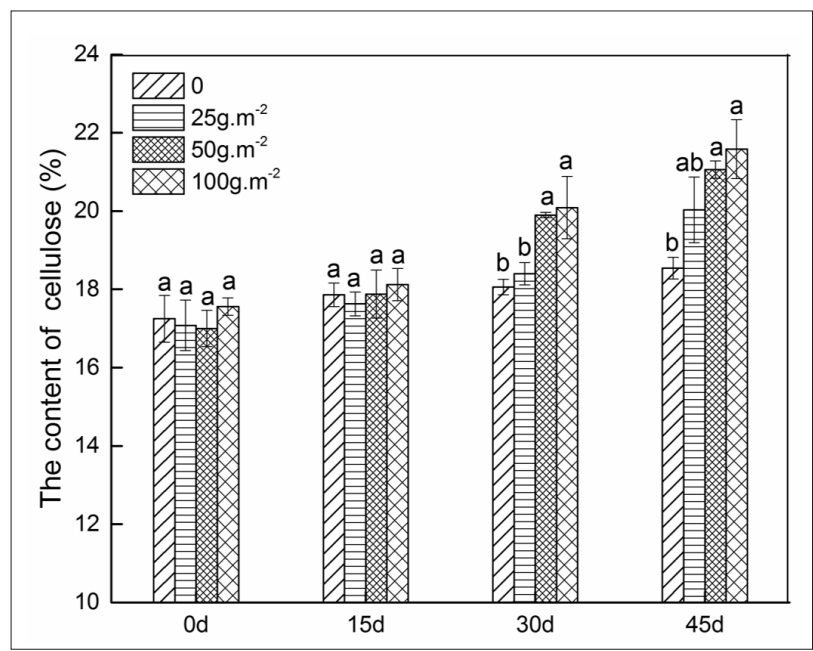

FIGURE 2. The variation of content of cellulose with different silicon fertilizer treatment. The vertical lines above histogram indicate mean \pm SE $(n=4)$. For each histogram, bars having different letters indicate significant difference $(\mathrm{P}<0.05)$ with different treatment on the same day.
The content of cellulose (Figure 2) and ADL (Figure 3) increased continuously with time after silicon fertilizer treatments. The content of these two cell wall components did not differ among the treatments at 0 and $15 \mathrm{~d}$, but significantly increased in plants treated with $50 \mathrm{~g} \mathrm{~m}^{-2}$ and $100 \mathrm{~g} \mathrm{~m}^{-2}$ silicon at 30 and $45 \mathrm{~d}$ compared to the control. There was no significant difference between $25 \mathrm{~g} \mathrm{~m}^{-2}$ silicon treatment and the control.

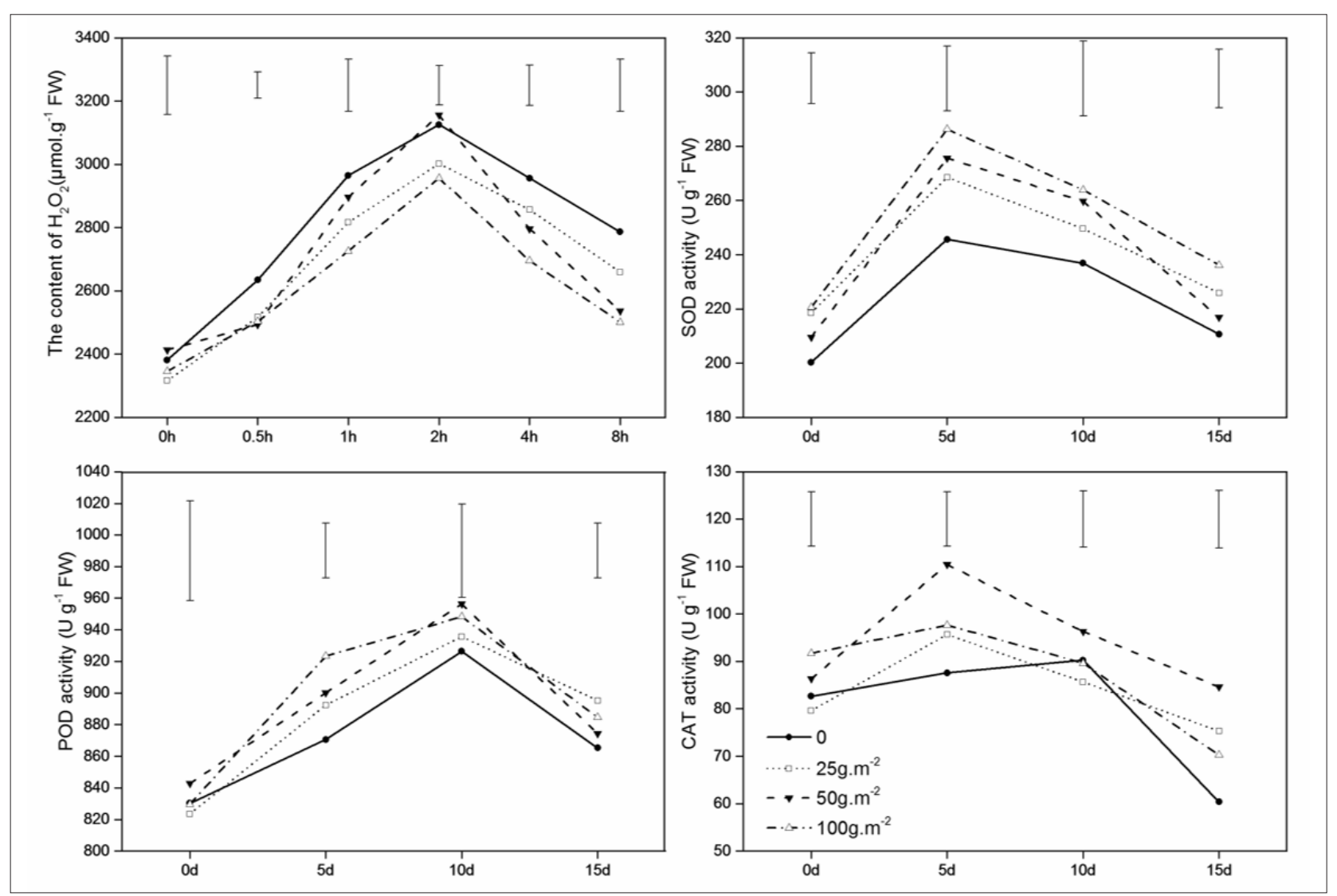

FIGURE 4. The variation of content of $\mathrm{H}_{2} \mathrm{O}_{2}$ and SOD/POD/CAT activity with different silicon fertilizer treatment after wear. Vertical bars on the top indicate least significant values $(\mathrm{P}<0.05)$ for treatment comparison. 


\section{$\mathrm{H}_{2} \mathrm{O}_{2}$ content and antioxidant enzyme activity after wear treatment}

$\mathrm{H}_{2} \mathrm{O}_{2}$ content after wear treatments was shown in Figure 4. $\mathrm{H}_{2} \mathrm{O}_{2}$ contents with different concentrations of silicon fertilizer applications were all significantly lower than the control at $0.5 \mathrm{~h}$. At $1 \mathrm{~h}$ and $2 \mathrm{~h}$ of wear treatment, only plants treated with $100 \mathrm{~g} \mathrm{~m}^{-2}$ of silicon fertilizer showed lower content of $\mathrm{H}_{2} \mathrm{O}_{2}$ than the control, while other treatments did not show significant differences compared with control. At $4 \mathrm{~h}$ and $8 \mathrm{~h}$ of wear treatment, $\mathrm{H}_{2} \mathrm{O}_{2}$ content with $50 \mathrm{~g} \mathrm{~m}^{-2}$ and $100 \mathrm{~g} \mathrm{~m}^{-2}$ silicon fertilizer were significantly lower than the control. Overall, enzyme activity of SOD, POD and CAT was increased firstly and then dropped under wear treatment. At $5 \mathrm{~d}$ of wear treatment, high level of Si treatment increased enzyme activity of SOD and POD, while low and middle level of Si treatment had no effect on the enzyme activity of SOD and POD. CAT activity was increased to the most by middle level of Si treatment. After 10 day of wear treatment, POD activity reached to the highest point. Enzyme activity of SOD and POD was not promoted by Si treatment at 15 day of stress while low and middle level of Si treatment increased CAT activity at this time point.

\section{Electrolyte leakage (EL) after wear treatment}

After wear treatment, leaf electrolyte leakages with silicon fertilizer treatments were shown in Figure 5. Electrolyte leakage declined to different extents after wear treatment for different silicon fertilizers at $0,5,10$, and $15 \mathrm{~d}$, compared with the control. The $100 \mathrm{~g} \mathrm{~m}^{-2}$ silicon fertilizer application was the only one that showed significant decreases of leaf EL on all sampling days, while $25 \mathrm{~g} \mathrm{~m}^{-2}$ application only showed

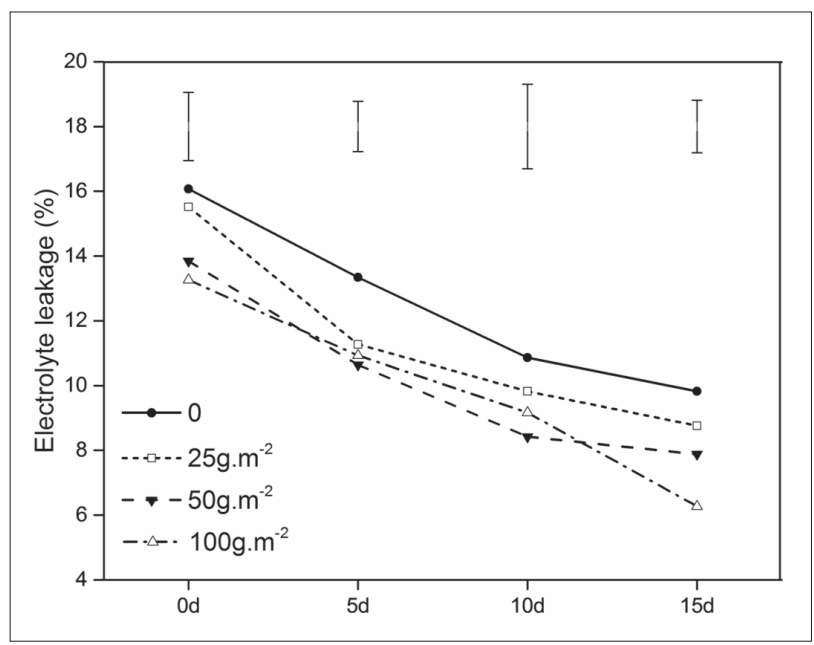

FIGURE 5. The variation of conductivity with different silicon fertilizer treatment after wear. Vertical bars on the top indicate least significant values $(\mathrm{P}<0.05)$ for treatment comparison significant decrease on $5 \mathrm{~d}$, and $50 \mathrm{~g} \mathrm{~m}^{-2}$ application on $5 \mathrm{~d}$ and $15 \mathrm{~d}$.

\section{MDA content after wear treatment}

During wear treatment, the leaf MDA contents in control and all concentrations of silicon fertilizer application increased and peaked on $5 \mathrm{~d}$, and then declined gradually (Figure 6). The leaf MDA contents with $50 \mathrm{~g} \mathrm{~m}^{-2}$ and $100 \mathrm{~g} \mathrm{~m}^{-2}$ application were significantly lower than that of the control on $0,5,10,15 \mathrm{~d}$.

\section{Turf quality after wear treatment}

After $15 \mathrm{~d}$ of wear treatment, turf treated with $50 \mathrm{~g} \mathrm{~m}^{-2}$ or $100 \mathrm{~g} \mathrm{~m}^{-2}$ of silicon fertilizer had significantly higher turf quality than the control. Turf treated with $25 \mathrm{~g} \mathrm{~m}^{-2}$ silicon fertilizer did not differ in turf quality compared to the control (Table 1).

\section{Discussion}

The thickness of the corneum was an important indicator for wear resistance of turfgrass. The results indicated that silicon was deposited in leaf epidermal and sclerenchyma with higher concentration of silicon fertilizer, then thickened cell wall and increased the sclerenchyma number, which have an underlying role in improving the mechanical strength of plant tissue. It is generally believed that the more thickened extent of the corneum of the epidermal cells are, the stronger the wear resistance of turfgrass would be (Ribichich et al., 2000). Plant tissue mechanical resistance can be considered one of the primary factors in determining turfgrass wear resistance (Lulli et al., 2011). Balsamo and Orkwiszewski (2008) found that tensile strength in leaves of Zea mays L. is

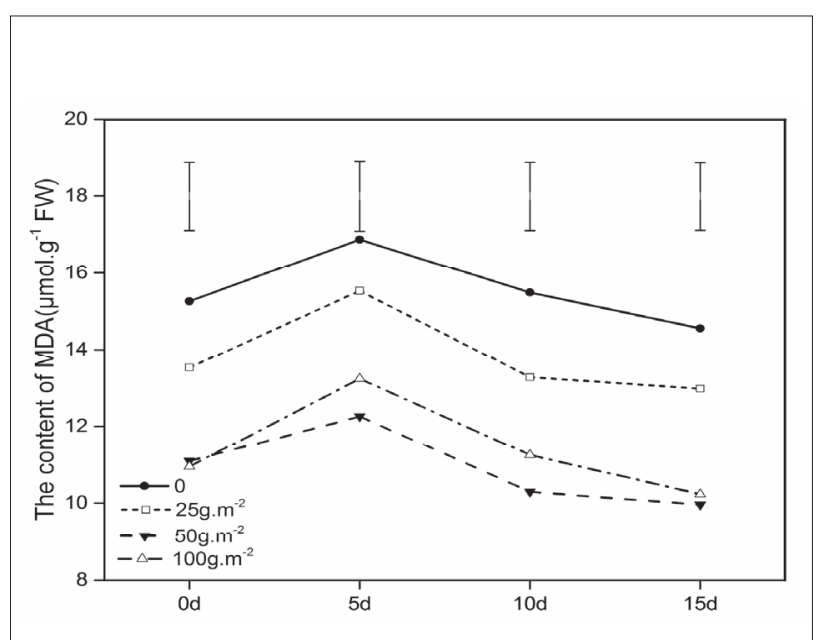

FIGURE 6. The variation of content of MDA with different silicon fertilizer treatment after wear. Vertical bars on the top indicate least significant values $(\mathrm{P}<0.05)$ for treatment comparison.

TABLE 1. The turf quality with different silicon fertilizer treatment after 15 days of wear.

\begin{tabular}{lccccc}
\hline \multirow{2}{*}{$\begin{array}{l}\text { Silicon fertilizer } \\
\left(\mathrm{g} \mathrm{m}^{-2}\right)\end{array}$} & \multicolumn{3}{c}{ Turf quality } & Score \\
\cline { 2 - 5 } & Density & Texture & Color & Uniformity & $4.0 \mathrm{a}$ \\
25 & 3.5 & 7.5 & 4.3 & 1 & $4.3 \mathrm{ab}$ \\
50 & 4.2 & 7.2 & 5.2 & 1 & $4.8 \mathrm{~b}$ \\
100 & 5.5 & 6.3 & 6.0 & 1 & $5.1 \mathrm{~b}$ \\
\hline
\end{tabular}

Note: LSD multiple comparison method, different small letters in the same column indicate significant difference at 0.05 level $(n=3)$. 
associated with the percentage of tissue lignification and the appearance of leaf architectural characters that are associated with the transition from the juvenile to the adult phase. Wright and Illius (1995) found that sclerenchyma and fiber content positively influenced the fracture properties of certain forage grasses and that fracture usually occurs at a zone of weakness at the intercalary meristem. It was found in this study that silicon fertilizer treatment could increase leaf cell wall thickness, especially under $100 \mathrm{~g} \mathrm{~m}^{-2}$. The average thickness of leaf corneum and the degree of corneum coverage were also obviously greater than the control, which was the result of silicon deposited in the cell wall. Moreover, silicon fertilizer treatment increased the amount of sclerenchyma, as a mechanical support, which provides strong protection for vascular bundle. The beneficial effects of Si have been thought to be due to the precipitation of amorphous silica in plants which acts as a mechanical barrier (Cheng, 1982; Jones and Handreck, 1967). It has been shown that Si also protects the plant by other processes which can boost the defense mechanisms, including the accumulation of lignin, phenolic compounds, and phytoalexins (Epstein, 1999; Fawe et al., 2001; Ma and Yamaji, 2006; Guntzer et al., 2012).

The influence of silicon fertilizer treatment on cellulose and lignin may be through adjusting the activity of related enzymes synthetize both of them or related gene expression. Ma and Fang (2004) studied the effect of silicon on potato's cytoderm and they found that the cellulose in cytoderm polysaccharides of the potato significantly increases after applying $5 \mathrm{mmol} \mathrm{L}^{-1} \mathrm{H}_{4} \mathrm{SiO}_{4}$ to MS culture medium for 30 days $(\mathrm{P}<0.05)$. Yang et al. (2003) found that Hoagland's nutrient solution with $1.7 \mathrm{mmol} \mathrm{L}^{-1} \mathrm{~K}_{2} \mathrm{O}_{3} \mathrm{Si}$ treatment can significantly increase the amount of lignin of wheat $(\mathrm{P}<0.05)$. In our study, the exogenous application of Si significantly increased cellulose and lignin content, which agrees with their observations.

The difference of cellulose and lignin between control and treatment were significant at $30 \mathrm{~d}$ and $45 \mathrm{~d}$ after the silicon fertilizer. In addition, $50 \mathrm{~g} \mathrm{~m}^{-2}$ and $100 \mathrm{~g} \mathrm{~m}^{-2}$ silicon fertilizer treatments also had higher contents of cellulose and lignin than others $(\mathrm{P}<0.05)$, which indicated that the accumulation of silicon in Kentucky bluegrass will take a period of time to impact cell wall structure. Therefore, in practice, the characteristic of the silicon fertilizer and the methods of treatment should be understood fully so that the fertilizer can function well.

Furthermore, high silicon concentration treatment significantly decreased the accumulation of $\mathrm{H}_{2} \mathrm{O}_{2}$ of Kentucky bluegrass after wear treatment, which is consistent with the research of Gong et al. (2005) who stated that application of Si can increase the antioxidant function and relieve oxidative stress of wheat. Electrons leaked from electron transport chains in the chloroplasts can react with $\mathrm{O}^{2-}$ to produce reactive oxygen species (ROS) such as hydrogen peroxide $\left(\mathrm{H}_{2} \mathrm{O}_{2}\right)$. The excess ROS may cause damage to the cell membrane through lipid peroxidation, proteins, and nucleic acids (Han et al., 2008). Song and Liang (2011) studied the physiological and molecular mechanisms of silicon-enhanced resistance of rice to high zinc stress, and they found that the SOD, CAT and ascorbate peroxidases (APX) activities were decreased by high $\mathrm{Zn}$ stress; the contents of hydrogen peroxide $\left(\mathrm{H}_{2} \mathrm{O}_{2}\right)$ and malondialdehyde (MDA) were increased by high $\mathrm{Zn}$ treatment, which were all counteracted by addition of Si. However, the relation of $\mathrm{H}_{2} \mathrm{O}_{2}$ content, wear resistance and Si treatment still remains unknown, which needs further research.

\section{Conclusions}

Under $100 \mathrm{~g} \mathrm{~m}^{-2}$ silicon fertilizer treatment, the corneum on the lower epidermis of the leaf was thickened, the coverage of corneum increased, and the number of the parts where the sclerenchyma of the leaf exists significantly increased. Cellulose and acid detergent lignin (ADL) with $50 \mathrm{~g} \mathrm{~m}^{-2}$ and $100 \mathrm{~g} \mathrm{~m}^{-2}$ silicon fertilizer treatments were significantly higher than control. The results indicated that silicon reinforced the mechanical strength of cell wall, which play a key role for enhancing wear resistance of turfgrass. After wear treatment, enzyme activity of SOD, POD and CAT significantly increased, while $\mathrm{H}_{2} \mathrm{O}_{2}$ accumulation, EL and MDA significantly declined with $50 \mathrm{~g} \mathrm{~m}^{-2}$ and $100 \mathrm{~g} \mathrm{~m}^{-2}$ of silicon fertilizer treatments, which indicates that silicon enhances the wear resistance of Poa pratensis via maintaining a stable membrane system and enhancing the antioxidative mechanism. After wear treatment, turf quality under $50 \mathrm{~g} \mathrm{~m}^{-2}$ or $100 \mathrm{~g} \mathrm{~m}^{-2}$ silicon fertilizer were significantly higher than the control. Our research revealed the silicon fertilizer and its proactive role in turfgrass wear tolerance, based on anatomical structure, physiological quality and biochemical activity, and thus served as an important reference for turfgrass management of urban landscapes, sports fields for soccer, tennis and golf courses under high traffic conditions.

\section{Acknowledgments}

This work was financially supported by Shenzhen Tech and Ecology \& Environment Company.

\section{References}

Balsamo, R.A., and Orkwiszewski, J.A.J. (2008). Leaf architecture, lignification, and tensile strength during vegetative phase change in Zea mays. Acta Soc. Bot. Pol. 77(3), 181-188.

Beard, J.B. (2005). Turfgrass Management for Golf Course. $2^{\text {nd }}$ ed. (Chelsea, MI: Sleeping Bear Press).

Bélanger, R.R., Benhamou, N., and Menzies, J.G. (2003). Cytological evidence of an active role of silicon in wheat resistance to powdery mildew (Blumeria graminis f. sp. tritici). J. Phytopathol. 93(4), 402412. https://doi.org/10.1094/PHYT0.2003.93.4.402.

Blum, H.D., and Ebercon, A. (1981). Cell membrane stability as a measure of drought and heat tolerance in wheat. J. Crop Sci. 21, 43-47. https://doi.org/10.2135/cropsci1981.0011183X002100010013x.

Bonos, S.A., Watkins, J., Honig, J.A., Sosa, M., Molnar, T., Murphy, J.A., and Meyer, W.A. (2001). Breeding cool season turfgrasses for wear tolerance using a wear simulator. J. Intl. Turfgrass Soc. Res. 9, 137145.

Brosnan, J.T., Ebdon, J.S., and Dest, W.M. (2005). Characteristics in diverse wear tolerant genotypes of Kentucky bluegrass. J. Crop Sci. 45, 1917-1926. https://doi.org/10.2135/cropsci2004.0511.

Canaway, P.M. (1981). Wear tolerance on turfgrass species. J. Sports Turf Res. Inst. 57, 65-83.

Carroll, M.J., and Petrovic, A.M. (1991). Wear tolerance of Kentucky bluegrass and creeping bentgrass following nitrogen and potassium application. J. Hort. Sci. 26, 851-853. https://doi.org/10.21273/ HORTSCI.26.7.851.

Chang, Z.L. (2004). Silicon nutrition of plants and silicon fertilizer's applications and popularize. J. Weifang College 2, 25-26.

Chen, N.L., Hu, M., and Qiao, C.P. (2010). The influence of BTH, SA and $\mathrm{SiO}_{2}$ treatment on resistance to powdery mildew of melon, HRGP of leaves and the amount of lignin. J. Sci. Agric. Sinica 43(3), 535-541. 
Chen, W., Yao, X., Cai, K., and Chen, J. (2011). Silicon alleviates drought stress of rice plants by improving plant water status, photosynthesis and mineral nutrient absorption. J. Biol. Trace Elem. Res. 142, 67-76. https://doi.org/10.1007/s12011-010-8742-x.

Cheng, B.T. (1982). Some significant functions of silicon to higher plants. J. Plant Nutr. 5, 1345-1353. https://doi. org/10.1080/01904168209363068.

Cotterill, J.V., Watkins, R.W., Brennon, C.B., and Cowan, D.P. (2007). Boosting silica levels in wheat leaves reduces grazing by rabbits J. Pest Manag. Sci. 63, 247-253. https://doi.org/10.1002/ps.1302.

Dellmer, D.P. (1999). Cellulose biosynthesis: exciting times for a difficult field of study. J. Annu. Rev. Plant Physiol. Plant Mol. Biol. 50, 245-276. https://doi.org/10.1146/annurevarplant.50.1.245.

Epstein, E. (1999). Silicon. J. Annu. Rev. Plant Physiol. Plant Mol. Bio. 50, 641-664. https://doi.org/10.1146/annurev.arplant.50.1.641.

Fawe, A., Menzies, J.G., Cherif, M., and Bélanger, R.R. (2001). Silicon and disease resistance in dicotyledons. In Silicon in Agriculture. Studies in Plant Science, 8. L.E. Datnoff, G.H. Snyder, and G.H. Korndorfer, eds. (Amsterdam: Elsevier), p. 159-169. https://doi. org/10.1016/S0928-3420(01)80013-6.

Geng, J.H., Zeng, J.F., and Chen, M.C. (1994). Comparison of the applications of Van Soest and conventional method to measure cellulose and lignin. J. Southwest Univ. for Nationalities (Natural Sciences) 20(1), 55-56.

Ghanmi, D., McNally, D.J., Benhamou, N., Menzies, J.G., and Bélanger, R.R. (2004). Powdery mildew of Arabidopsis thaliana: a pathosystem for exploring the role of silicon in plant-microbe interactions. J. Physiol. Mol. Plant P. 64, 189-199. https://doi.org/10.1016/j. pmpp.2004.07.005.

Giannopolitis, C.N., and Ries, S.K. (1977). Superoxide dismutases: I. Occurrence in higher plants. J. Plant Physiol. 59, 309-314. https:// doi.org/10.1104/pp.59.2.309.

Gong, H.J., Zhu, X.Y., Chen, K.M., Wang, S.M., and Zhang, C.L. (2005) Silicon alleviates oxidative damage of wheat plants in pots under drought. J. Plant Sci. 169, 313-321. https://doi.org/10.1016/j. plantsci.2005.02.023.

Guntzer, F., Keller, C., and Meunier, J.D. (2012). Benefits of plant silicon for crops: a review. J. Agron. Sustain Dev. 32(1), 201-213. https://doi.org/10.1007/s13593-011-0039-8.

Han, L.B., Song, G.L., and Zhang, X.Z. (2008). Preliminary observations on physiological responses of three turfgrass species to traffic stress. J. Hort. Tech. 18(1), 139-143. https://doi.org/10.21273/HORTTECH.18.1.139.

Hartley, S.E.R., Fitt, N., McLarnon, E.L., and Wade, R.N. (2015). Defending the leaf surface: Intra- and inter-specific differences in silicon deposition in grasses in response to damage and silicon supply. J. Front Plant Sci. 6(35), 1-8. https://doi.org/10.3389/ fpls.2015.00035.

Heath, R.L., and Packer, L. (1968). Photoperoxidation in isolated chloroplasts: I. Kinetics and stoichiometry of fatty acid peroxidation. J. Arch. Biochem. Biophys. 125, 189-198. https://doi. org/10.1016/0003-9861(68)90654-1.

Hunt, J.W., Dean, A.P., Webster, R.E., Johnson, G.N., and Ennos, A.R. (2008). A novel mechanism by which silica defends grasses against herbivory. Annals of Botany 102, 653-656. https://doi.org/10.1093/ aob/mcn 130 .

Isa, M., Bai, S., Yokoyama, T., Ma, J.F., Ishibashi, Y., Yuasa, T., and IwayaInoue, M. (2010). Silicon enhances growth independent of silica deposition in a low-silica rice mutant, lsi1. Plant Soil 331(1-2), 361375. http://doi:10.1007/s11104-009-0258-9.

John, J.J., O’Malley, D.M., Presnell, T., Booker, F.L., Campbell, M.M., Whetten, R.W., and Sederoff, R.R. (1997). Inheritance gene expression and lignin characterization in a mutant pine deficient in cinnamyl alcohol dehydrogenase. Proc. Natl. Acad. Sci. USA 94, 8255-9260. https://doi.org/10.1073/pnas.94.15.8255.

Jones, L.H.P., and Handreck, K.A. (1967). Silica in soils, plants, and animals. Adv. Agron. 19, 104-149. https://doi.org/10.1016/S00652113(08)60734-8

Kido, N., Yokoyama, R., Yamamoto, T., Furukawa, J., Iwai, H., Satoh, S., and Nishitani, K. (2015). The matrix polysaccharide $(1 ; 3,1 ; 4)-\beta$-dglucan is involved in silicon-dependent strengthening of rice cell wall. Plant Cell Physiol. 56(2), 268-276. http://doi:10.1093/pcp/ pcu162.

Kim, Y.H., Khan, A.L., Kim, D.H., Lee, S.Y., Kim, K.M., Waqas, M., Jung, H.Y., Shin, J.H., Kim, J.G., and Lee, I.J. (2014). Silicon mitigates heavy metal stress by regulating P-type heavy metal ATPases, Oryza sativa low silicon genes, and endogenous phytohormones. BMC Plant Biol. 14, 13. https://doi.org/10.1186/1471-2229-14-13.

Liu, S.T., Han, X.G., Dong, X.W., Wang, W.H., and Zhong, H.M. (1997). Study of silicon's influence on stress resistance of wheat. J. Laiyang Agric. College 14(1), 21-25.

Lulli, F., Guglielminetti, L., Gross, N., Armeni, R., Stefanini, S., and Volterrani, M. (2011). Physiological and morphological factors influencing leaf, rhizome and stolon tensile strength in C-4 turfgrass species. Funct. Plant Biol. 38(11), 919-926. https://doi. org/10.1071/FP11070.

Ma, J.F. (2004). Role of silicon in enhancing the resistance of plants to biotic and abiotic stresses. Soil Sci. Plant Nutr. 50(1), 11-18. https:// doi.org/10.1080/00380768.2004.10408447.

Ma, J.F. (2005). Plant root responses to three abundant soil minerals: silicon, aluminum and iron. J. Crit. Rev. Plant Sci. 24, 267-281. https://doi.org/10.1080/07352680500196017.

Ma, J.F., and Yamaji, N. (2006). Silicon uptake and accumulation in higher plants. J. Trends Plant Sci. 11, 392-397. https://doi. org/10.1016/j.tplants.2006.06.007.

Ma, X.L., and Fang, J.Y. (2004). Silicon's influence on roots growth of in vitro potato platelet and the cell wall components. J. Huangshan College 6(6), 85-86.

Mansour, M.M.F. (2012). Plasma membrane permeability as an indicator of salt tolerance in plants. J. Biol. Plant. 57(1), 1-10. https://doi.org/10.1007/s10535-012-0144-9.

Massey, F.P., Ennos, A.R., and Hartley, S. (2007). Grasses and the resource availability hypothesis: the importance of silica-based defences. J. Ecol. 95, 414-424. https://doi:10.1111/j.13652745.2007.01223.x.

Rémus-Borel, W., Menzies, J.G., and Bélanger, R.R. (2005). Silicon induces antifungal compounds in powdery mildew-infected wheat. J. Physiol. Mol. Plant. P. 66, 108-115. https://doi.org/10.1016/j. pmpp.2005.05.006.

Rémus-Borel, W., Menzies, J.G., and Bélanger, R.R. (2009). Aconitate and methyl aconitate are modulated by silicon in powdery mildewinfected wheat plants. Plant Physiol. 166, 1413-1422. https:// doi.org/10.1016/j.jplph.2009.02.011.

Ribichich, K.F., Lopez, S.E., and Vegetti, A.C. (2000). Histopathological spikelet changes produced by Fusarium graminearum in susceptible and resistant wheat cultivars. Plant Dis. 84, 794-802. https://doi. org/10.1094/PDIS.2000.84.7.794.

Schoelynck, J., and Struyf, E. (2016). Silicon in aquatic vegetation. J. Funct. Ecol. 30(8), 1323-1330. https://doi.org/10.1111/13652435.12614

Schoelynck, J., Bal, K., Backx, H., Okruszko, T., Meire, P., and Struyf, E. (2010). Silica uptake in aquatic and wetland macrophytes: a strategic choice between silica, lignin and cellulose? New Phytol. 186, 385-391. https://doi.org/10.1111/j.1469-8137.2009.03176.x. 
Shearman, R.C., and Beard, J.B. (1973). Nitrogen and potassium effects on turfgrass wear tolerance. Ann. Michigan Turfgrass Conf. Proc. 2, 25-26.

Shearman, R.C., and Beard, J.B. (1975). Turfgrass wear tolerance mechanisms: II. Effects of cell constituents on turfgrass wear tolerance. J. Agron. 67(2), 211-215

Shearman, R.C., and Beard, J.B. (1975). Turfgrass wear tolerance investigations. USGA Green Section Record. 13, 7-9.

Song, A.L., and Liang, Y.C. (2011). The physiological and molecular mechanisms of silicon-enhanced resistance of rice to high zinc stress. (Beijing: M. Chinese Academy of Agricultural Science).

Sun, D., and Liddle, M.J. (1993). Trampling resistance, stem flexibility and leaf strength in nine Australian grasses and herbs. J. Biol. Conserv. 65, 35-41. https://doi.org/10.1016/0006-3207(93)90194-6.

Trenholm, L.E., Carrow, R.N., and Duncan, R.R. (2000). Mechanism of wear tolerance in seashore paspalum and bermudagrass. Crop Sci. 40(5), 1350-1357. https://doi.org/10.2135/cropsci2000.4051350x.

Trenholm, L.E., Duncan, R.R., Carrow, R.N., and Snyder, G.H. (2001). Influence of silica on growth, quality and wear tolerance of seashore paspalum. J. Plant Nutr. 24, 245-259. https://doi.org/10.1081/PLN100001385

Valente, A., Morais, R., Couto, C., and Correia, J.H. (2004). Modeling, simulating and testing of a silicon soil moisture sensor based on the dual-probe heat-pulse method. J. Sensor Actuat. A-Phys. 115(2), 434-439. https://doi.org/10.1016/j.sna.2004.04.056.

Velikova, V., Yordavow, I., and Edreva, A. (2000). Oxidative stress and some antioxidant systems in acid rain-treated bean plants: Protective role of exogenous polyamines. Plant Sci. 151, 59-66. https://doi.org/10.1016/S0168-9452(99)00197-1.

Wang, L.J., Guo, Z.M., and Li, T.J. (1999). Biomineralization nanostructure materials and silicon nutrition of plants. J. Prog. Chem. 11(2), 119-128.

Wang, Y., Zhang, M., Zhang, X., and Dong, H. (2002). Comparative studies on elasticity and scrape tolerance characters of Zoysia japonica and Poa pratensis. J. Pratacultural Sci. 19(2), 56-59.

Wright, W., and Illius, A.W. (1995). A comparative study of the fracture properties of five grasses. Funct. Ecol. 9, 269-278. http:// www.jstor.org/stable/2390573.

Yang, Y.F., Liang, Y.C., Lou, Y.S., and Sun, W.C. (2003). The influence of silicon on peroxidase, SOD, lignin and powdery mildew resistance. Sci. Agric. Sinica 3(7), 813-817.

Yoshida, S., Ohnishi, Y., and Kitagishi, K. (1962). Histochemistry of Si in rice tissues. III. The presence of cuticle-silica double layer in the epidermal tissue. Soil Sci. Plant Nutr. 8(2), 1-5. https://doi.org/10.1 080/00380768.1962.10430982.

Zhang, G., Cui, Y., Ding, X., and Dai, Q. (2013). Stimulation of phenolic metabolism by silicon contributes to rice resistance to sheath blight. Plant Nutr. Soil Sci. 176(1), 118-124. http://doi:10.1002/ jpln.201200008.

Zhang, J., and Kirkham, M.B. (1996). Antioxidant responses to drought in sunflower and sorghum seedlings. New Phytol. 132, 361373. https://doi.org/10.1111/j.1469-8137.1996.tb01856.x.

Zhang, Q., Liu, J.C., Lu, H.L., Zhao, S.Z., Wang, W.Y., Du, J.N., and Yan, C.L. (2015). Effects of silicon on growth, root anatomy, radial oxygen loss (ROL) and Fe/Mn plaque of Aegiceras corniculatum L. Blanco seedlings exposed to cadmium. Env. Nanotech Monit. Manag. 4,6-11.
Received: Jun. 26, 2017

Accepted: Sep. 22, 2017

Addresses of authors:

Jinbo Li ${ }^{1}$, Shigang $\mathrm{Li}^{2}$, Lixin $\mathrm{Xu}^{1}$, Xuehua Puyang ${ }^{2}$,

Yangfan Zheng ${ }^{1}$, Guilong Song ${ }^{1, *}$ and $\mathrm{Yi} \mathrm{Xu}^{3, * *}$

${ }^{1}$ Turfgrass Research Institute, Beijing Forestry University,

35 Qinghua East Road, Beijing, 100083, China

${ }^{2}$ Shenzhen Tech and Ecology \& Environment Co. Ltd., 2018 Xuegang Road, Shenzhen, 518040, China

${ }^{3}$ Department of Plant Biology, Rutgers University, 59 Dudley

Road, New Brunswick, NJ 08901, USA

Corresponding authors:

* E-mail: syihan@163.com

**E-mail: yx109@scarletmail.rutgers.edu 